\begin{tabular}{c}
\hline Review of \\
ECONOMICS \\
and \\
INSTITUTIONS \\
\hline
\end{tabular}

\title{
Recent Trends in Household Wealth, 1983-2009: the Irresistible Rise of Household Debt
}

\author{
Edward Nathan Wolff $\bowtie$ \\ New York University
}

\begin{abstract}
I find here that the early and mid 2000s (2001 to 2007) witnessed both exploding debt and a consequent "middle class squeeze." Median wealth grew briskly in the late 1990s and even faster in the 2000s. The inequality of net worth was up slightly during the 2000s. Indebtedness, which fell substantially during the late 1990s, skyrocketed in the early and mid 2000s. Among the middle class, the debt-income ratio reached its highest level in 24 years. The disparity in wealth holdings between AfricanAmerican and white households was about the same in 2007 as in 1983, though Hispanics did show some relative gains on non-Hispanic whites over the years 2001 to 2007. Young households (under the age of 45) after some relative gains from 1983 to 1989, saw their relative wealth position deteriorate over the years 1989 to 2007. Projections to July 2009 on the basis of changes in stock and housing prices suggest that median wealth plunged by 36 percent and there was a fairly steep rise in wealth inequality, with the Gini coefficient advancing from 0.834 to 0.865 .
\end{abstract}

JEL classification: D31, J15

Keywords: household wealth, inequality, racial inequality, portfolio composition

\section{Introduction}

The 1990s witnessed some remarkable events. The stock market boomed. On the basis of the Standard \& Poor (S\&P) 500 index, stock prices surged 171 percent between 1989 and 2001. Stock ownership spread and by 2001 (as we shall see below) over half of U.S. households owned stock either directly or indirectly. Real wages, after stagnating for many years, finally grew in the late 1990s. According to Bureau of Labor Statistics

\footnotetext{
$\triangle$ Address: Department of Economics, New York University, 19 West 4 th Street, New York, NY 10012 - 1119, USA. (Phone: 001-212-9988917, Fax: 001-212-9954186, Email: edward.wolff@nyu.edu)
}

\section{Recommended Citation}

Wolff, E.N. (2010). Recent Trends in Household Wealth, 1983-2009: the Irresistible Rise of Household Debt. Review of Economics and Institutions, 2(1), Article 4. doi: 10.5202/rei.v2i1.4. Retrieved from http://www.rei.unipg.it/rei/article/view/26 
(BLS) figures, real mean hourly earnings gained 8.3 percent between 1995 and 2001. ${ }^{1}$

However, 2001 saw a recession (albeit a short one). Moreover, the stock market peaked in 2000 and dropped steeply from 2000 to 2003 but recovered in 2004, so that between 2001 and 2004 the S\&P 500 was down by "only" 12 percent in real terms. ${ }^{2}$ Real wages rose very slowly from 2001 to 2004, with the BLS real mean hourly earnings up by only 1.5 percent, and median household income dropped in real terms by 1.5 percent. $^{3} \mathrm{On}$ the other hand, housing prices rose steeply. The median sales price of existing one-family homes rose by 18 percent in real terms nationwide. ${ }^{4}$ The other big story was household debt, particularly that of the middle class, which skyrocketed during these years, as we shall see below.

From 2004 to 2007, the stock market rebounded. The S\&P 500 rose 19 percent in real terms. Over the period from 2001 to 2007, the S\&P 500 was up 6 percent in real terms. Real wage remained stagnant, with the BLS real mean hourly earnings rising by only 1.0 percent. Median household income in real terms showed some growth over this period, rising by 3.2 percent. From 2001 to 2007 it gained 1.6 percent. From 2004 to 2007 housing prices slowed, with the median sales price of existing one-family homes nationwide advancing by only 1.7 percent over these years in real terms. Over the years 2001 to 2007 real housing prices gained 19 percent.

Updating previous studies (see Wolff, 1994, 1996, 1998, 2001, 2002, and 2007), I find that median net worth, the wealth of the average household, demonstrated robust growth over the years from 1983 to 2007. In fact, the growth rate of median wealth accelerated from the 1980s to the 1990s and into the 2001-2007 period. However, the gains of the 2001-2007 period were based largely on rising home prices financed by increasing mortgage debt. This growth came to an abrupt end in 2007 with the collapse in home prices, and median wealth plummeted from 2007 through 2009.

Household wealth inequality increased sharply between 1983 and 1989. However, this was followed by a period of almost no change in household

\footnotetext{
${ }^{1}$ These figures are based on the BLS hourly wage series. The source is Table B-47 of the Economic Report of the President, 2009, available at http://www.gpoaccess.gov/eop/tables09.html. The BLS wage figures are converted to constant dollars on the basis of the Consumer Price Index (CPI - U).

${ }^{2}$ The source is Table B-96 of the Economic Report of the President, 2009, available at http://www.gpoaccess.gov/eop/tables09.html. The Census Bureau uses the newer CPI-U-RS series to convert to constant dollars. However, for this period, there is virtually no difference between the CPI-U and the CPI-U-RS.

${ }^{3}$ The source is Table B-33 of the Economic Report of the President, 2009, available at http://www.gpoaccess.gov/eop/tables09.html.

${ }^{4}$ The source is Table 935 of the 2009 Statistical Abstract, US Bureau of the Census, available at http://www.census.gov/compendia/statab/.
} 
wealth inequality from 1989 to 2007. In contrast, projections to 2009 suggest a large rise in wealth inequality from 2007 to 2009.

Despite the buoyant economy over the 1980s and 1990s, overall indebtedness continued to rise among American families and then skyrocketed in the early and mid 2000s. Among the middle class, the debtincome ratio reached its highest level in 24 years. The high level of indebtedness made the middle class particularly vulnerable to the collapse of the housing market at the end of the decade of the 2000s.

There was also a noticeable expansion of stock ownership from 1989 to 2001 but this was followed by a mild contraction between 2001 and 2007 . This development made household wealth particularly vulnerable to the stock market downturn of 2007 to 2009.

The ratio of mean wealth between African-American and white families was very low in 1983, at 0.19, and barely budged over the years 1983 to 2007. However, Hispanics did show some relative gains over the 2001 to 2007 period. Young households (under the age of 45) after some relative gains from 1983 to 1989, saw their relative wealth position deteriorate over the years 1989 to 2007 .

I begin in the next section, Section 2, with a discussion of the measurement of household wealth and a description of the data sources used for this study. Section 3 presents results on time trends in median and average wealth holdings, Section 4 on changes in the concentration of household wealth, and Section 5 on the composition of household wealth. Section 6 investigates changes in wealth holdings by race and ethnicity; and Section 7 reports on changes in the age-wealth profile. Section 8 provides details on stock ownership and in Section 9 I provide a partial update of household wealth trends to 2009. A summary of results and concluding remarks are provided in Section 10.

\section{Data Sources and Methods}

The data sources used for this study are the 1983, 1989, 2001, and 2007 Survey of Consumer Finances (SCF) conducted by the Federal Reserve Board. ${ }^{5}$ Each survey consists of a core representative sample combined with a high-income supplement. In 1983, for example, the supplement was drawn from the Internal Revenue Service's Statistics of Income data file. For the 1983 SCF, an income cut-off of $\$ 100,000$ of adjusted gross income was used as the criterion for inclusion in the supplemental sample.

\footnotetext{
${ }^{5}$ The Survey of Consumer Finances was also conducted in years 1992, 1995, 1998, and 2004. I choose these particular years since they highlight important developments over the full 1983-2007 period.
} 
Individuals were randomly selected for the sample within pre-designated income strata. In later years, the high income supplement was selected as a list sample from statistical records (the Individual Tax File) derived from tax data by the Statistics of Income Division of the Internal Revenue Service (SOI). This second sample was designed to disproportionately select families that were likely to be relatively wealthy (see, for example, Kennickell, 2001, for a more extended discussion of the design of the list sample in the 2001 SCF). The advantage of the high-income supplement is that it provides a much "richer" sample of high income and therefore potentially very wealthy families. However, the presence of a high-income supplement creates some complications, because weights must be constructed to meld the high-income supplement with the core sample. ${ }^{6}$

The principal wealth concept used here is marketable wealth (or net worth), NW, which is defined as the current value of all marketable or fungible assets less the current value of debts. Net worth is thus the difference in value between total assets and total liabilities or debt. Total assets are defined as the sum of: (1) the gross value of owner-occupied housing; (2) other real estate owned by the household; (3) cash and demand deposits; (4) time and savings deposits, certificates of deposit, and money market accounts; (5) government bonds, corporate bonds, foreign bonds, and other financial securities; (6) the cash surrender value of life insurance plans; (7) the cash surrender value of pension plans, including IRAs, Keogh, and 401(k) plans; (8) corporate stock and mutual funds; (9) net equity in unincorporated businesses; and (10) equity in trust funds. Total liabilities are the sum of: (1) mortgage debt, (2) consumer debt, including auto loans, and (3) other debt.

This measure reflects wealth as a store of value and therefore a source of potential consumption. I believe that this is the concept that best reflects the level of well-being associated with a family's holdings. Thus, only assets that can be readily converted to cash (that is, "fungible" ones) are included. As a result, consumer durables such as automobiles, televisions, furniture, household appliances, and the like, are excluded here, since these items are not easily marketed, with the possible exception of vehicles, or their resale value typically far understates the value of their consumption services to the household. Another justification for their exclusion is that this treatment is consistent with the national accounts, where purchase of vehicles is counted as expenditures, not savings. Also excluded here is the value of future social security benefits the family may receive upon retirement (usually referred to as "Social Security wealth"), as

\footnotetext{
${ }^{6}$ For a discussion of some of the issues involved in developing these weights, see, for example, Kennickell and Woodburn (1992) for the 1989 SCF and Kennickell (2001) for the 2001 SCF.
} 
well as the value of Defined Benefit pension benefits from private pension plans ("DB pension wealth").

Another concept that we will make use of later on is "housing wealth." This is defined as net home equity, the difference between the (gross) market value of a home and its outstanding mortgage debt.

\section{Median Wealth Rose Briskly during the 2000s}

Table 1 documents a robust growth in wealth during the 1990s. After rising by 7 percent between 1983 and 1989, median wealth (the wealth of the household in the middle of the distribution) was 16 percent greater in 2001 than in 1989. As a result, median wealth grew slightly faster between 1989 and 2001, 1.3 percent per year, than between 1983 and 1989, at 1.1 percent per year. However, between 2001 and 2007, median wealth grew even faster, by 19 percent overall or 2.9 percent per year. Most of the increase (63 percent) in median net worth emanated from the pronounced rise in home prices.

Table 1 - Mean and Median Household Wealth and Income, 1983-2007 (in thousands, 2007 dollars)

\begin{tabular}{l} 
Wealth Concept \\
\cline { 5 - 9 }
\end{tabular}

Mean net worth also showed a sharp increase from 1983 to 1989 of 15 percent and then, buoyed largely by rising stock prices, another surge of 44 percent to 2001. There was an additional rise of 20 percent in 2007. Overall, its 2007 value was almost double its value in 1983 and about three quarters larger than in 1989. Mean wealth grew quite a bit faster between 1989 and 2001, at 3.0 percent per year, than from 1983 to 1989, at 2.3 percent per year. There was then a slight increase in wealth growth from 2001 to 2007 to 3.1 percent per year. This modest acceleration was due largely to the rapid increase in housing prices of 19 percent in real terms over the six years counterbalanced by the reduced growth in stock prices between 2001 and 2007 in comparison to 1989 to 2001, and to the fact that 
housing comprised 28 percent and (total) stocks made up 25 percent of total assets in 2001. Another point of note is that mean wealth grew about twice as fast as the median between 1983 and 2007, indicating widening inequality of wealth over these years.

Median household income (based on Current Population Survey data), after gaining 11 percent between 1983 and 1989, grew by only 2.3 percent (in total) from 1989 to 2001 and by another 1.6 percent between 2001 and 2007, for a net change of 16 percent from 1983 to 2007. In contrast, mean income rose by 16 percent from 1983 to 1989, by another 12 percent from 1989 to 2001, then fell by 0.8 percent from 2001 to 2007 , for a total change of 28 percent from 1983 to 2007. Between 1983 and 2007, mean income grew about twice as fast as median income.

In sum, while household income virtually stagnated for the average American household over the 1990s and 2000s, median net worth showed robust gains over this period. In the 2000s, in particular, mean and median income changed very little while mean and median net worth grew strongly.

\section{Wealth Inequality Shows Little Change over the Early and Mid 2000s}

The figures in Table 2 also show that wealth inequality, after rising steeply between 1983 and 1989, remained virtually unchanged from 1989 to 2007. The share of wealth held by the top 1 percent rose by 3.6 percentage points from 1983 to 1989 and the Gini coefficient increased from 0.80 to 0.83 . Between 1989 and 2007, the share of the top percentile actually declined sharply, from 37.4 to 34.6 percent, though this was more than compensated for by an increase in the share of the next four percentiles. As a result, the share of the top five percent increased from 58.9 percent in 1989 to 61.8 percent in 2007, and the share of the top quintile rose from 83.5 to 85.0 percent. The share of the fourth and middle quintiles each declined by about a percentage point from 1989 to 2007, while that of the bottom 40 percent increased by almost one percentage point. Overall, the Gini coefficient was virtually unchanged -- 0.832 in 1989 and 0.834 in 2007.

The top 1 percent of families (as ranked by income on the basis of the SCF data) earned 21 percent of total household income in 2006 and the top 20 percent accounted for 61 percent -- large figures but lower than the corresponding wealth shares. ${ }^{7}$ The time trend for income inequality also

\footnotetext{
${ }^{7}$ It should be noted that the income in each survey year (say 2007) is for the preceding year (2006 in this case).
} 
contrasts with that for net worth. Income inequality increased sharply between 1982 and 1988, with the Gini coefficient rising from 0.48 to 0.52 and the share of the top one percent from 12.8 to 16.6 percent. There was again a pronounced increase in income inequality between 1988 and 2000, with the share of the top one percent rising from 16.6 to 20.0 percent, that of the top quintile from 55.6 to 58.6 percent, and the Gini coefficient from 0.52 to $0.56 .^{8}$

Table 2 - The Size Distribution of Wealth and Income, 1983-2007

\begin{tabular}{|c|c|c|c|c|c|c|c|c|c|c|}
\hline \multirow[b]{2}{*}{ Year } & \multirow[b]{2}{*}{$\begin{array}{c}\text { Gini } \\
\text { Coefficient }\end{array}$} & \multicolumn{9}{|c|}{ Percentage Share of Wealth or Income held by: } \\
\hline & & $\begin{array}{l}\text { Top } \\
1.0 \%\end{array}$ & $\begin{array}{l}\text { Next } \\
4.0 \%\end{array}$ & $\begin{array}{l}\text { Next } \\
5.0 \%\end{array}$ & $\begin{array}{c}\text { Next } \\
10.0 \%\end{array}$ & $\begin{array}{c}\text { Top } \\
20.0 \%\end{array}$ & $\begin{array}{c}4^{\text {th }} \\
20.0 \%\end{array}$ & $\begin{array}{c}3^{\text {rd }} \\
20.0 \%\end{array}$ & $\begin{array}{c}\text { Bottom } \\
40.0 \%\end{array}$ & All \\
\hline \multicolumn{11}{|c|}{ A. Net Worth } \\
\hline 1983 & 0.799 & 33.8 & 22.3 & 12.1 & 13.1 & 81.3 & 12.6 & 5.2 & 0.9 & 100.0 \\
\hline 1989 & 0.832 & 37.4 & 21.6 & 11.6 & 13.0 & 83.5 & 12.3 & 4.8 & -0.7 & 100.0 \\
\hline 2001 & 0.826 & 33.4 & 25.8 & 12.3 & 12.9 & 84.4 & 11.3 & 3.9 & 0.3 & 100.0 \\
\hline 2007 & 0.834 & 34.6 & 27.3 & 11.2 & 12.0 & 85.0 & 10.9 & 4.0 & 0.2 & 100.0 \\
\hline \multicolumn{11}{|c|}{ B. Income (SCF) } \\
\hline 1982 & 0.480 & 12.8 & 13.3 & 10.3 & 15.5 & 51.9 & 21.6 & 14.2 & 12.3 & 100.0 \\
\hline 1988 & 0.521 & 16.6 & 13.3 & 10.4 & 15.2 & 55.6 & 20.6 & 13.2 & 10.7 & 100.0 \\
\hline 2000 & 0.562 & 20.0 & 15.2 & 10.0 & 13.5 & 58.6 & 19.0 & 12.3 & 10.1 & 100.0 \\
\hline 2006 & 0.574 & 21.3 & 15.9 & 9.9 & 14.3 & 61.4 & 17.8 & 11.1 & 9.6 & 100.0 \\
\hline
\end{tabular}

Source: own computations from the 1983, 1989, 2001 and 2007 SCF. For the computation of percentile shares of net worth, households are ranked according to their net worth; and for percentile shares of income, households are ranked according to their income. See Appendix for sources and methods.

The years between 2000 and 2006 saw a slight abatement in the rise of income inequality. Over these years, the Gini coefficient for income rose from 0.56 to 0.57 , the share of the top one percent from 20.0 to 21.3 percent, and that of the top quintile from 15.2 to 15.9 percent. All in all, the 2000s witnessed a moderate increase in income inequality and a very slight rise in wealth inequality. ${ }^{9}$

${ }^{8}$ The SCF data show a much higher level of income inequality than the CPS data. In the year 2000, for example, the CPS data show a share of the top five percent of 22.1 percent and a Gini coefficient of 0.462 . The difference is primarily due to three factors. First, the SCF oversamples the rich (as noted above), while the CPS is a representative sample. Second, the CPS data are topcoded (that is, there is an open-ended interval at the top, typically at $\$ 75,000$ or $\$ 100,000$ ), whereas the SCF data are not. Third, the income concepts differ between the two samples. In particular, the SCF income definition includes realized capital gains whereas the CPS definition does not. However, the CPS data also show a large increase of inequality between 1989 and 2000, with the share of the top five percent rising from 18.9 to 22.1 percent and the Gini coefficient from 0.431 to 0.462 . Further analysis of the difference in income figures between the two surveys is beyond the scope of this paper.

9 The slight rise in wealth inequality between 2001 and 2007 appears due to two offsetting effects. As shown in my previous work (Wolff, 2002), wealth inequality is positively related to both income inequality and the ratio of stock prices to house prices. Between 2001 and 2007, the Gini 


\section{Household Debt Explodes}

The portfolio composition of household wealth shows the forms in which households save. This aspect is important when we try to understand how wealth changes over time and the exposure to household wealth to asset price changes.

In 2007, owner-occupied housing was the most important household asset in the breakdown shown in Table 3, accounting for 33 percent of total assets. However, net home equity -- the value of the house minus any outstanding mortgage -- amounted to only 21 percent of total assets. Real estate, other than owner-occupied housing, comprised 11 percent, and business equity another 20 percent.

Demand deposits, time deposits, money market funds, CDs, and the cash surrender value of life insurance made up 7 percent and pension accounts 12 percent. Bonds and other financial securities amounted to 2 percent; corporate stock, including mutual funds, to 12 percent; and trust equity to 2 percent. Debt as a proportion of gross assets was 15 percent, and the debt-equity ratio (the ratio of total household debt to net worth) was 0.18 .

There have been some notable changes in the composition of household wealth over the period between 1983 and 2007. The first is the steep rise in the share of gross housing wealth in total assets. After fluctuating between 28 and 30 percent from 1983 to 2001, the proportion jumped to 33 percent in 2007. There were two factors behind this. The first is the rise in the homeownership rate, which, according to the SCF data, climbed from 63 percent in 1983 to 69 percent in 2007. The second is the sharp rise in housing prices, noted above. Between 2001 and 2007, the median house price for existing one-family homes rose by 19 percent in real terms. The rise in housing prices by itself would have caused the share of housing in total assets to rise by 5.3 percentage points, compared to the actual increase of 4.6 percentage points.

coefficient for household income, as noted above, rose modestly from 0.562 to 0.574 while the ratio of the Standard \& Poor 500 stock index to the median sales price of existing one-family homes fell from 8.1 to 7.1. These two effects generally offset each other, resulting in a small rise in wealth inequality. 
Table 3 - Composition of Total Household Wealth, 1983 - 2007, (percent of gross assets)

\begin{tabular}{|c|c|c|c|c|}
\hline Wealth component & 1983 & 1989 & 2001 & 2007 \\
\hline Principal residence (gross value) & 30.1 & 30.2 & 28.2 & 32.8 \\
\hline Other real estate (gross value) ${ }^{a}$ & 14.9 & 14.0 & 9.8 & 11.3 \\
\hline Unincorporated business equity ${ }^{b}$ & 18.8 & 17.2 & 17.2 & 20.1 \\
\hline Liquid assets ${ }^{c}$ & 17.4 & 17.5 & 8.8 & 6.6 \\
\hline Pension accounts ${ }^{d}$ & 1.5 & 2.9 & 12.3 & 12.1 \\
\hline Financial securities $^{\mathrm{e}}$ & 4.2 & 3.4 & 2.3 & 1.5 \\
\hline Corporate stock and mutual funds & 9.0 & 6.9 & 14.8 & 11.8 \\
\hline Net equity in personal trusts & 2.6 & 3.1 & 4.8 & 2.3 \\
\hline Miscellaneous assets $^{f}$ & 1.3 & 4.9 & 1.8 & 1.7 \\
\hline Total & 100.0 & 100.0 & 100.0 & 100.0 \\
\hline Debt on principal residence & 6.3 & 8.6 & 9.4 & 11.4 \\
\hline All other debt ${ }^{\mathrm{g}}$ & 6.8 & 6.4 & 3.1 & 3.9 \\
\hline Total debt & 13.1 & 15.0 & 12.5 & 15.3 \\
\hline \multicolumn{5}{|l|}{ Memo (selected ratios in percent): } \\
\hline Debt / equity ratio & 15.1 & 17.6 & 14.3 & 18.1 \\
\hline Debt / income ratio & 68.4 & 87.6 & 81.1 & 118.7 \\
\hline Net home equity / total assets ${ }^{h}$ & 23.8 & 21.6 & 18.8 & 21.4 \\
\hline Principal residence debt / house value & 20.9 & 28.6 & 33.4 & 34.9 \\
\hline Stocks, directly or indirectly owned / total assets ${ }^{i}$ & 11.3 & 10.2 & 24.5 & 16.8 \\
\hline
\end{tabular}

Source: own computations from the 1983, 1989, 2001 and 2007 SCF.

a. In 2001 and 2007 this equals the gross value of other residential real estate plus the net equity in non-residential real estate.

b. Net equity in unincorporated farm and non-farm businesses and closely-held corporations.

c. Checking accounts, savings accounts, time deposits, money market funds, certificates of deposits, and the cash surrender value of life insurance.

d. IRAs, Keogh plans, 401(k) plans, the accumulated value of defined contribution pension plans, and other retirement accounts.

e. Corporate bonds, government bonds (including savings bonds), open-market paper, and notes.

f. Gold and other precious metals, royalties, jewelry, antiques, furs, loans to friends and relatives, future contracts, and miscellaneous assets.

g. Mortgage debt on all real property except principal residence; credit card, installment, and other consumer debt.

h. Ratio of gross value of principal residence less mortgage debt on principal residence to total assets.

i. Includes direct ownership of stock shares and indirect ownership through mutual funds, trusts, and IRAs, Keogh plans, $401(\mathrm{k})$ plans, and other retirement accounts.

A third and related trend is that net equity in owner-occupied housing (the difference between the market value and outstanding mortgages on the property), after falling from 24 percent in 1983 to 19 percent in 2001, picked up to 21 percent in 2007. The difference between the two series (gross versus net housing values as a share of total assets) is attributable to the changing magnitude of mortgage debt on homeowner's property, which increased from 21 percent in 1983 to 35 percent in 2007. Moreover, mortgage debt on principal residence climbed from 9.4 to 11.4 percent of total assets between 2001 and 2007. The fact that net home equity as a proportion of assets increased between 2001 and 2007 reflected the strong gains in real estate values over these years. 
Third, overall indebtedness first fell slightly, with the debt-equity ratio declining from 15 percent in 1983 to 14 percent in 2001. However, it then jumped to 18 percent in 2007. In contrast, the ratio of debt to total income increased from 68 percent in 1983 to 81 percent in 2001 and then skyrocketed to 119 percent in 2007, its high for this period. If mortgage debt on principal residence is excluded, then the ratio of other debt to total assets fell off from 6.8 percent in 1983 to 3.9 percent in 2007. One implication is that over the 1990s and 2000s families used tax-sheltered mortgages and home equity loans rather than consumer loans and other forms of consumer debt to finance consumption.

A fourth development was the pronounced growth of defined contribution pension accounts, which rose moderately from 1.5 percent of total assets in 1983 to 2.9 percent in 1989 and then shot up to 12 percent in 2001, where it remained in 2007. This increase largely offset the decline in the share of liquid assets in total assets, from 17 percent in 1983 to 7 percent in 2007, so that it is reasonable to conclude that households have to a large extent substituted tax-deferred defined contribution pension accounts for taxable savings deposits.

Fifth, the share of corporate stock and mutual funds in total assets rose rather briskly from 9 in 1983 to 15 percent in 1998, stayed at this level in 2001, and then plummeted to 12 percent in 2007. If we include the value of stocks indirectly owned through mutual funds, trusts, IRAs, 401(k) plans, and other retirement accounts, then the value of total stocks owned as a share of total assets more than doubled from 11 percent in 1983 to 25 percent in 2001 but then tumbled to 17 percent in 2007. The rise during the 1990s reflected the bull market in corporate equities as well as increased stock ownership, while the decline in the 2000s was a result of the relatively small rise in the stock market over this period (particularly relative to housing prices) as well as a drop in stock ownership (see Table 10a below). The change in stock prices by itself would have caused the share of total stocks in assets to fall by 4 percentage points between 2001 and 2004, compared to the actual decline of 8 percentage points. Most of the decline in the share of stocks in total assets was due to sales of stocks and withdrawals from stock funds.

\subsection{Portfolio Composition by Wealth Class}

The tabulation in Table 3 provides a picture of the average holdings of all families in the economy, but there are marked class differences in how middle-class families and the rich invest their wealth. These differences in portfolio composition are important because they affect how wealth changes over time for different parts of the wealth distribution and thus how overall wealth inequality develops. 
As shown in Table 4, the richest one percent of households (as ranked by wealth) invested over three quarters of their savings in real estate, businesses, corporate stock, and financial securities in 2007. Corporate stocks, either directly owned by the households or indirectly owned through mutual funds, trust accounts, or various pension accounts, comprised 21 percent by themselves. Housing accounted for only 10 percent of their wealth (and net equity in housing only 9 percent), liquid assets another 5 percent, and pension accounts another 6 percent. Their ratio of debt to net worth was only 3 percent, their ratio of debt to income was 39 percent, and the ratio of mortgage debt to house value was 15 percent.

Table 4 - Composition of Household Wealth by Wealth Class, 2007, (percent of gross assets)

\begin{tabular}{|c|c|c|c|c|}
\hline \multirow{2}{*}{ Asset } & \multicolumn{2}{|c|}{ All Top One } & \multirow{2}{*}{$\begin{array}{l}\text { Next } 19 \\
\text { Percent }\end{array}$} & \multirow{2}{*}{$\begin{array}{l}\text { Middle } 3 \\
\text { Quintiles }\end{array}$} \\
\hline & Households & Percent & & \\
\hline Principal residence & 32.8 & 10.2 & 31.8 & 65.1 \\
\hline $\begin{array}{l}\text { Liquid assets (bank deposits, money market funds, and cash } \\
\text { surrender value of life insurance) }\end{array}$ & 6.6 & 4.5 & 7.3 & 7.8 \\
\hline Pension accounts & 12.1 & 5.8 & 15.9 & 12.9 \\
\hline $\begin{array}{l}\text { Corporate stock, financial securities, mutual funds, and } \\
\text { personal trusts }\end{array}$ & 15.5 & 25.2 & 15.0 & 3.6 \\
\hline Unincorporated business equity other real estate & 31.3 & 52.3 & 28.5 & 9.3 \\
\hline Miscellaneous assets & 1.7 & 2.0 & 1.6 & 1.3 \\
\hline Total assets & 100.0 & 100.0 & 100.0 & 100.0 \\
\hline \multicolumn{5}{|l|}{ Memo (selected ratios in percent): } \\
\hline Debt/equity ratio & 18.1 & 2.8 & 12.1 & 61.1 \\
\hline Debt/income ratio & 118.7 & 39.4 & 109.8 & 156.7 \\
\hline Net home equity/total assets ${ }^{a}$ & 21.4 & 8.7 & 23.6 & 34.8 \\
\hline Principal residence debt/house value & 34.9 & 15.2 & 25.6 & 46.6 \\
\hline All stocks/total assets ${ }^{b}$ & 16.8 & 21.4 & 18.6 & 7.0 \\
\hline
\end{tabular}

Source: own computations from the 2007 SCF. Households are classified into wealth class according to their net worth. Brackets for 2007 are:

Top one percent: Net worth of $\$ 8,232,000$ or more.

Next 19 percent: Net worth between $\$ 473,000$ and $\$ 8,232,000$.

Quintiles 2 through 4: Net worth between $\$ 200$ and $\$ 473,000$.

Also, see Notes to Table 3.

a. Ratio of gross value of principal residence less mortgage debt on principal residence to total assets.

b. Includes direct ownership of stock shares and indirect ownership through mutual funds, trusts, and IRAs, Keogh plans, 401(k) plans, and other retirement accounts.

Among the next richest 19 percent of U.S. households, housing comprised 32 percent of their total assets (and net home equity 24 percent), liquid assets another 7 percent, and pension assets 16 percent. Forty-four percent of their assets took the form of investment assets - real estate, business equity, stocks, and bonds - and 19 percent was in the form of stocks directly or indirectly owned. Debt amounted to 12 percent of 
their net worth and 110 percent of their income, and the ratio of mortgage debt to house value was 26 percent.

In contrast, almost two thirds of the wealth of the middle three wealth quintiles of households was invested in their own home in 2007. However, home equity amounted to only 35 percent of total assets, a reflection of their large mortgage debt. Another 21 percent went into monetary savings of one form or another and pension accounts. Together housing, liquid assets, and pension assets accounted for 86 percent of the total assets of the middle class. The remainder was about evenly split among non-home real estate, business equity, and various financial securities and corporate stock. Stocks directly or indirectly owned amounted to only 7 percent of their total assets. The ratio of debt to net worth was 61 percent, substantially higher than for the richest 20 percent, and their ratio of debt to income was 157 percent, also much higher than the top quintile. Finally, their mortgage debt amounted to almost half the value of their principal residences.

The rather staggering debt level of the middle class in 2007 raises the question of whether this is a recent phenomenon or whether it has been going on for some time. The overall debt-equity ratio in 2007 was only slightly above its level in 1989, while the overall debt-income ratio generally trended upward since 1983 and actually took a big jump from 2001 to 2007.

Table 5 compares the wealth composition of the three wealth classes in 1983 and 2007.

Table 5 - Composition of Household Wealth by Wealth Class,1983 and 2007, (percent of gross assets)

\begin{tabular}{|c|c|c|c|c|c|c|}
\hline \multirow[t]{2}{*}{ Component } & \multicolumn{2}{|c|}{$\begin{array}{l}\text { Top One } \\
\text { Percent }\end{array}$} & \multicolumn{2}{|c|}{$\begin{array}{l}\text { Next } 19 \\
\text { Percent }\end{array}$} & \multicolumn{2}{|c|}{$\begin{array}{l}\text { Middle } 3 \\
\text { Quintiles }\end{array}$} \\
\hline & 1983 & 2007 & 1983 & 2007 & 1983 & 2007 \\
\hline Principal residence & 8.1 & 10.2 & 29.1 & 31.8 & 61.6 & 65.1 \\
\hline $\begin{array}{l}\text { Liquid assets (bank deposits, money market funds, and cash } \\
\text { surrender value of life insurance) }\end{array}$ & 8.5 & 4.5 & 21.4 & 7.3 & 21.4 & 7.8 \\
\hline Pension accounts & 0.9 & 5.8 & 2.0 & 15.9 & 1.2 & 12.9 \\
\hline $\begin{array}{l}\text { Corporate stock, financial securities, mutual funds, and personal } \\
\text { trusts }\end{array}$ & 29.5 & 25.2 & 13.0 & 15.0 & 3.1 & 3.6 \\
\hline Unincorporated business equity other real estate & 52.0 & 52.3 & 32.8 & 28.5 & 11.4 & 9.3 \\
\hline Miscellaneous assets & 1.0 & 2.0 & 1.6 & 1.6 & 1.3 & 1.3 \\
\hline Total assets & 100.0 & 100.0 & 100.0 & 100.0 & 100.0 & 100.0 \\
\hline \multicolumn{7}{|l|}{ Memo: } \\
\hline Debt/equity ratio & 5.9 & 2.8 & 10.9 & 12.1 & 37.4 & 61.1 \\
\hline Debt/income ratio & 86.8 & 39.4 & 72.8 & 109.8 & 66.9 & 156.7 \\
\hline
\end{tabular}

There is remarkable stability in the composition of wealth by wealth class between 1983 and 2007. The most notable exception is a substitution 
of pension assets for liquid assets - a transition that occurred for all three wealth classes but that was particularly marked for percentiles 80-99 and for the middle three quintiles. The debt-equity ratio actually fell for the top one percent from 1983 and 2007, as did the debt-income ratio. The debt-income ratio increased slightly for the next 19 percent, while the debt-income ratio rose sharply, from 73 to 110 percent.

Among the middle three wealth quintiles, pension accounts rose as a share of total assets by almost 12 percentage points (and the proportion of households with a pension account surged by 41 percentage points) from 1983 to 2007 while liquid assets declined as a share by 14 percentage points. This set of changes paralleled that of all households. The share of all stocks in total assets mushroomed from 2.4 percent in 1983 to 13 percent in 2001 and then fell off to 7 percent in 2007 as stock prices stagnated.

Changes in debt, however, were much more dramatic. There was a sharp rise in the debt-equity ratio of the middle class from 37 percent in 1983 to 61 percent in 2007. The rise was much steeper than at the aggregate level. The debt to income ratio skyrocketed over this period, more than doubling. Here, too, much of the increase happened between 2001 and 2007. Moreover, the increase was much steeper than in the aggregate. In fact, in 1983, the debt to income ratio was about the same for middle class as for all households but by 2007 the ratio was much larger. As for all households, net home equity as a percentage of total assets fell for the middle class from 1983 to 2007 and mortgage debt as a proportion of house value rose.

The rising indebtedness of the middle class, particularly in the form of mortgage debt, made it very vulnerable to the home price collapse of 20072009. As we shall see below, there was a large reduction in median wealth over this period, as well as a substantial increase in the share of homeowners whose mortgage debt was greater than their home values (so-called "underwater"). Though the rich were more heavily invested in stocks than the middle class, stocks did not constitute nearly as high a percentage of their wealth as homes did for the middle class, and the stock market meltdown of 2007-2009 did not hurt the rich as much as the home price collapse hurt the middle class.

\section{The Racial Divide Remains Largely Unchanged over Time}

Striking differences are found in the wealth holdings of different racial and ethnic groups. In Tables 6 and 7, households are divided into three 
groups: (i) non-Hispanic whites, (ii) non-Hispanic African-Americans, and (iii) Hispanics. ${ }^{10}$

Table 6 - Household Income and Wealth by Race, 1983-2007, (in thousands, 2007 dollars)

\begin{tabular}{|c|c|c|c|c|c|c|}
\hline \multirow[b]{2}{*}{ Year } & \multicolumn{3}{|c|}{ Means } & \multicolumn{3}{|c|}{ Medians } \\
\hline & $\begin{array}{l}\text { Non-Hispanic } \\
\text { Whites }\end{array}$ & $\begin{array}{c}\text { Non-Hispanic } \\
\text { African-Americans }\end{array}$ & Ratio & $\begin{array}{l}\text { Non-Hispanic } \\
\text { Whites }\end{array}$ & $\begin{array}{c}\text { Non-Hispanic } \\
\text { African-Americans }\end{array}$ & Ratio \\
\hline \multicolumn{7}{|c|}{ A. Income } \\
\hline 1982 & 64.8 & 34.9 & 0.54 & 45.6 & 25.4 & 0.56 \\
\hline 1988 & 71.0 & 31.6 & 0.45 & 47.3 & 17.9 & 0.38 \\
\hline 2000 & 88.9 & 43.0 & 0.48 & 51.5 & 29.3 & 0.57 \\
\hline 2006 & 92.3 & 44.6 & 0.48 & 50.0 & 30.0 & 0.60 \\
\hline \multicolumn{7}{|c|}{ B. Net Worth } \\
\hline 1983 & 316.0 & 59.5 & 0.19 & 91.0 & 6.1 & 0.07 \\
\hline 1989 & 373.9 & 62.7 & 0.17 & 108.1 & 2.8 & 0.03 \\
\hline 2001 & 545.3 & 77.7 & 0.14 & 124.6 & 12.5 & 0.10 \\
\hline 2007 & 652.1 & 122.7 & 0.19 & 143.6 & 9.3 & 0.06 \\
\hline \multicolumn{7}{|c|}{ C. Homeownership Rate (in Percent) } \\
\hline 1983 & 68.1 & 44.3 & 0.65 & - & - & - \\
\hline 1989 & 69.3 & 41.7 & 0.60 & - & - & - \\
\hline 2001 & 74.1 & 47.4 & 0.64 & - & - & - \\
\hline 2007 & 74.8 & 48.6 & 0.65 & - & - & - \\
\hline
\end{tabular}

Source: own computations from the 1983, 1989, 2001, and 2007 SCF

Households are divided into four racial/ethnic groups: (I) non-Hispanic whites; (ii) non-Hispanic blacks; (iii) Hispanics; and (iv) American Indians, Asians, and others. For 1995, 1998, and 2001, the classification scheme does not explicitly indicate non-Hispanic whites and non-Hispanic blacks for the first two categories so that some Hispanics may have classified themselves as either whites or blacks.

In 2007, while the ratio of mean incomes between (non-Hispanic) white and (non-Hispanic) black households was an already low 0.48 and the ratio of median incomes was 0.60 , and the ratios of mean and median wealth holdings were even lower, at 0.19 and 0.06 , respectively. ${ }^{11}$ The homeownership rate for black households was 49 percent in 2007, a little less than two thirds the rate among whites, and the percentage of black households with zero or negative net worth stood at 33.4, more than double the corresponding percentage among whites.

Between 1982 and 2006, while the average real income of non-Hispanic white households increased by 42 percent and the median by 10 percent, the former rose by only 28 percent for non-Hispanic black households but

\footnotetext{
${ }^{10}$ The residual group, American Indians and Asians, is excluded here because of its small sample size.

${ }^{11}$ It should be stressed that the unit of observation is the household, which includes both families (two or more related individuals living together), as well as single adults. As is widely known, the share of female-headed households among African-Americans is much higher than that among whites. This difference partly accounts for the relatively lower income and wealth among AfricanAmerican households.
} 
the latter by 18 percent. As a result, the ratio of mean income slipped from 0.54 in 1982 to 0.48 in 2006, while the ratio of median income rose from 0.56 to 0.60 .

Between 1983 and 2001, average net worth (in 2007 dollars) rose by a whopping 73 percent for whites but only by 31 percent for black households, so that the net worth ratio fell from 0.19 to 0.14 . Most of the slippage occurred between 1989 and 2001, when white net worth surged by a spectacular 46 percent and black net worth advanced by only a respectable 24 percent. Indeed, mean net worth growth among black households was actually much higher in the 1989-2001 years than in the years from 1983 to 1989 (only a 5 percent gain). The difference in the 19892001 period was the huge increase in household wealth among white households. However, between 2001 and 2007, mean net worth among black households gained an astounding 58 percent while white wealth advanced only 29 percent, so that by 2007 the net worth ratio was back to 0.19 , the same level as in 1983.

Table 7 - Household Family Income and Wealth for Non-Hispanic Whites and Hispanics, 1983-2007 (in thousands, 2007 dollars)

\begin{tabular}{|c|c|c|c|c|c|c|}
\hline \multirow[b]{2}{*}{ Year } & \multicolumn{3}{|c|}{ Means } & \multicolumn{3}{|c|}{ Medians } \\
\hline & $\begin{array}{c}\text { Non-Hispanic } \\
\text { Whites }\end{array}$ & Hispanic & Ratio & $\begin{array}{l}\text { Non-Hispanic } \\
\text { Whites }\end{array}$ & Hispanic & Ratio \\
\hline \multicolumn{7}{|c|}{ A. Income } \\
\hline 1982 & 64.8 & 39.2 & 0.60 & 45.6 & 30.2 & 0.66 \\
\hline 1988 & 71.0 & 32.4 & 0.46 & 47.3 & 22.7 & 0.48 \\
\hline 2000 & 88.9 & 44.0 & 0.50 & 51.5 & 28.1 & 0.55 \\
\hline 2006 & 92.3 & 46.4 & 0.50 & 50.0 & 35.0 & 0.70 \\
\hline \multicolumn{7}{|c|}{ B. Net Worth } \\
\hline 1983 & 316.0 & 51.4 & 0.16 & 91.0 & 3.5 & 0.04 \\
\hline 1989 & 373.9 & 61.5 & 0.16 & 108.1 & 2.3 & 0.02 \\
\hline 2001 & 545.3 & 93.8 & 0.17 & 124.6 & 3.5 & 0.03 \\
\hline 2007 & 652.1 & 170.4 & 0.26 & 143.6 & 9.1 & 0.06 \\
\hline \multicolumn{7}{|c|}{ C. Homeownership Rate (in Percent) } \\
\hline 1983 & 68.1 & 32.6 & 0.65 & - & - & - \\
\hline 1989 & 69.3 & 39.8 & 0.60 & - & - & - \\
\hline 2001 & 74.1 & 44.3 & 0.60 & - & - & - \\
\hline 2007 & 74.8 & 49.2 & 0.66 & - & - & - \\
\hline
\end{tabular}

Source: own computations from the 1983, 1989, 2001, and 2007 SCF.

See footnote to Table 6 for details on racial/ethnic categories.

It is not clear how much of the sharp drop in the racial wealth gap between 1989 and 2001 and the turnaround between 2001 and 2007 is due to actual wealth changes in the African-American community and how much is due to sampling variability (since the sample sizes of nonHispanic African Americans are relatively small in all years). However, 
one salient difference between the two groups is the much higher share of stocks in the white portfolio and the much higher share of homes in the portfolio of black households. In 2001, the gross value of principal residences formed 46 percent of the gross assets of black households and only 27 percent that of white households, while (total) stocks were 25 percent of the total assets of whites and only 15 percent that of black households. ${ }^{12}$ Moreover, while the debt to asset ratio was higher for black than white households in 2001 (0.32 versus 0.12$)$, the ratio among black households rose to 0.36 in 2007 . For whites the debt to asset ratio increased slightly, to 0.13 in 2007.

In the case of median wealth, the black-white ratio first increased from 7 to 10 percent between 1983 and 2001 but then slipped to 6 percent in 2007. In this case, median wealth for white households grew by 15 percent between 2001 and 2004 but dropped by 26 percent among black households, reflecting in part the rising share of black households with zero or negative net worth.

The homeownership rate of black households grew from 44 to 47 percent between 1983 and 2001 but relative to white households, the homeownership rate fell off a bit from a ratio of 0.65 in 1983 to 0.64 in 2001. The change over these years primarily reflected a big jump in the white homeownership rate, of 6 percentage points. However, from 2001 to 2007, the black homeownership rate gained 1.2 percentage points and the white homeownership rate 0.7 percentage points, so that homeownership rate ratio recovered a bit to 0.65 by 2007 .

The picture is somewhat different for Hispanics (see Table 7). The ratio of mean income between Hispanics and non-Hispanic whites in 2007 was 0.50, almost the same as that between African-American and white households. However, the ratio of median income was 0.70 , much higher than the 0.60 ratio between black and white households. The ratio of mean net worth was 0.26 compared to a ratio of 0.19 between blacks and whites. However, the ratio of medians was 0.06 , almost identical to those between blacks and whites. The Hispanic homeownership rate was 49 percent, almost identical to that of non-Hispanic black households.

Developments among Hispanic households over the period from 1983 to 2007 were generally a positive story. Mean household income for Hispanics grew by 18 percent and median household income by 16 percent, so that while the ratio of mean income between Hispanics and non-Hispanic whites slid from 60 to 50 percent, that of median income advanced from 66 to 70 percent. In fact, from 2001 to 2007 median income

\footnotetext{
${ }^{12}$ Also, see Gittleman and Wolff (2004) for additional evidence from the Panel Study of Income Dynamics (PSID).
} 
for Hispanics grew by an astonishing 25 percent while that for nonHispanic whites declined by 3 percent.

Between 1983 and 2001, mean wealth almost doubled for Hispanic households and the ratio of mean net worth between Hispanics and NonHispanic whites improved slightly from 16 percent in 1983 to 17 percent in 2001. However, from 2001 to 2007 mean net worth among Hispanics climbed by another 82 percent while that of whites gained 20 percent, so that the corresponding wealth ratio advanced to 26 percent, quite a bit higher than that between black and white households.

On the other hand, from 1983 to 2007, median wealth among Hispanics remained extremely low and largely unchanged, so that the ratio of median wealth between Hispanics and non-Hispanic whites stayed virtually the same. While the homeownership rate among Hispanic households climbed from 33 to 44 percent between 1983 and 2001, the ratio of homeownership rates between Hispanics and non-Hispanic whites actually slipped from 0.65 to 0.60 . However, between 2001 and 2007, the Hispanic homeownership rose once again, to 49 percent, about the same as black households, and the homeownership ratio recovered to 0.66.

Despite some progress from 2001 to 2007, the respective wealth gaps between blacks and whites and between Hispanics and non-Hispanic whites were still much greater than the corresponding income gaps in 2007. While mean income ratios were of the order of 50 percent, mean wealth ratios were of the order of 20 to 25 percent. While blacks and Hispanics were left out of the wealth surge of the years 1989 to 2001 because of relatively low stock ownership (see Section 8 below for more details), they actually benefited from this (and the relatively high share of houses in their portfolio) in the 2001-2007 period. ${ }^{13}$

\section{Wealth Shifts from the Young to the Old}

As shown in Table 8, the cross-sectional age-wealth profiles of 1983, 1989, 2001, and 2007 generally follow the predicted hump-shaped pattern of the life-cycle model (see, for example, Modigliani and Brumberg, 1954). Mean wealth increases with age up through age 65 or so and then falls off. Homeownership rates also have a similar profile, though the fall-off after

\footnotetext{
${ }^{13}$ One important reason for the wealth gap is differences in inheritances. According to my calculations from the SCF data, 24.1 percent of white households in 1998 reported receiving an inheritance over their life time, compared to 11.0 percent of black households, and the average bequest among white inheritors was 115 thousand dollars (present value in 1998) and only 32 thousand dollars among black inheritors. Thus, inheritances appear to play a vital role in explaining the large wealth gap, particularly in light of the fact that black families appear to save more than white families at similar income levels (see, for example, Blau and Graham, 1990; Oliver and Shapiro, 1997; and Gittleman and Wolff, 2004).
} 
the peak age is much more attenuated than for the wealth numbers. In 2007, the wealth of elderly households (age 65 and over) averaged 75 percent higher than the non-elderly and their homeownership rate was 21 percentage points higher.

Table 8 - Age-Wealth Profiles and Homeownership Rates by Age, 1983-2007

\begin{tabular}{lllll}
\hline \hline Age & $\mathbf{1 9 8 3}$ & $\mathbf{1 9 8 9}$ & $\mathbf{2 0 0 1}$ & $\mathbf{2 0 0 7}$ \\
\hline A. Mean Net Worth (Ratio to Overall Mean) & & & & \\
Overall & 1.00 & 1.00 & 1.00 & 1.00 \\
Under 35 & 0.21 & 0.29 & 0.19 & 0.17 \\
$35-44$ & 0.71 & 0.72 & 0.64 & 0.58 \\
$45-54$ & 1.53 & 1.50 & 1.25 & 1.19 \\
$55-64$ & 1.67 & 1.58 & 1.86 & 1.69 \\
$65-74$ & 1.93 & 1.61 & 1.72 & 1.86 \\
75 \& over & 1.05 & 1.26 & 1.20 & 1.16 \\
B. Homeownership Rate (in Percent) & & & & \\
Overall & 63.4 & 62.8 & 67.7 & 68.6 \\
Under 35 & 38.7 & 36.3 & 40.2 & 40.8 \\
35-44 & 68.4 & 64.1 & 67.6 & 66.1 \\
$45-54$ & 78.2 & 75.1 & 76.1 & 77.3 \\
$55-64$ & 77.0 & 79.2 & 83.2 & 80.9 \\
$65-74$ & 78.3 & 78.1 & 82.5 & 85.5 \\
75 \& over & 69.4 & 70.2 & 76.2 & 77.0 \\
\hline \hline Source: own computations from the 1983, 1989, 2001, and 2007 SCF. Households are classified according to the age of \\
the householder & & & & \\
& & &
\end{tabular}

Despite the apparent similarity in the profiles, there have been notable shifts in the relative wealth holdings of age groups between 1983 and 2007. The relative wealth of the youngest age group, under 35 years of age, expanded from 21 percent of the overall mean in 1983 to 29 percent in 1989 but then collapsed to only 17 percent in 2007. In 2007, the mean wealth of the youngest age group was $\$ 91,200$, which was only slightly more than the mean wealth of this age group in $1989(\$ 88,500)$. The mean net worth of the next youngest age group, 35-44, relative to the overall mean showed a slight increase from 1983 to 1989 and then tumbled from 0.72 in 1989 to 0.58 in 2007. The relative wealth of the next youngest age group, 45-54, also declined rather steadily over time, from 1.53 in 1983 to 1.19 in 2007. The relative wealth of age group 55-64, after falling between 1983 and 1989, advanced from 1.58 in 1989 to 1.69 in 2007. The relative net worth of age group 65-74 plummeted from 1.93 in 1983 to 1.61 in 1989 but then regained most of the lost ground, reaching 1.86 in 2007. The wealth of the oldest age group, age 75 and over, advanced from a ratio of 1.05 in 1983 to 1.16 in 2007. At least over the period from 1989 to 2007, there was a clear shift in relative wealth holdings away from younger households (under age 55) and toward those in age group 55 to 74 . 
Changes in homeownership rates tend to mirror these trends. While the overall ownership rate increased by 5.2 percentage points from 63.4 to 68.6 percent between 1983 and 2007, the share of households in the youngest age group owning their own home increased by only 2.1 percentage points. The homeownership rate of households between 35 and 44 of age actually fell by 2.3 percentage points, and that of age group 45 to 54 years of age declined by 0.9 percentage points. Big gains in homeownership were recorded by the older age groups: 3.9 percentage points for age group 55-64, 7.1 percentage points for age group 65-74, and 7.6 percentage points for the oldest age group. By 2007, homeownership rates rose monotonically with age up to age group 65-74 and then dropped for the oldest age group. The statistics point to a relative shifting of home ownership away from younger towards older households between 1983 and 2007.

Changes in the relative wealth position of different age groups depend in large measure on differences in asset composition and relative asset price movements. The former are highlighted in Table 9 for the year 2007.

Table 9 - Composition of Household Wealth by Age Class, 2007 (percent of gross assets)

\begin{tabular}{|c|c|c|c|c|c|c|c|}
\hline Asset & All & Under 35 & $35-44$ & $45-54$ & $55-64$ & $65-74$ & 75 \& over \\
\hline Principal residence & 32.8 & 54.3 & 43.7 & 33.8 & 25.6 & 28.2 & 30.2 \\
\hline $\begin{array}{l}\text { Liquid assets (bank deposits, money } \\
\text { market funds, and cash surrender } \\
\text { value of life insurance) }\end{array}$ & 6.6 & 5.7 & 5.4 & 6.4 & 6.3 & 6.1 & 10.5 \\
\hline Pension accounts & 12.1 & 6.0 & 10.7 & 13.0 & 15.8 & 12.9 & 5.0 \\
\hline $\begin{array}{l}\text { Corporate stock, financial } \\
\text { securities }{ }^{a} \text {, mutual funds, and } \\
\text { personal trusts }\end{array}$ & 15.5 & 4.2 & 8.6 & 13.1 & 16.4 & 20.5 & 25.6 \\
\hline $\begin{array}{l}\text { Unincorporated business equity, } \\
\text { other real estate }\end{array}$ & 31.3 & 28.7 & 30.1 & 32.0 & 34.4 & 30.2 & 27.1 \\
\hline Miscellaneous assets & 1.7 & 1.2 & 1.5 & 1.7 & 1.5 & 2.1 & 1.6 \\
\hline Total assets & 100.0 & 100.0 & 100.0 & 100.0 & 100.0 & 100.0 & 100.0 \\
\hline \multicolumn{8}{|l|}{ Memo (selected ratios in percent): } \\
\hline Debt/equity ratio & 18.1 & 92.7 & 41.3 & 20.2 & 11.9 & 7.1 & 2.1 \\
\hline Debt/income ratio & 118.7 & 167.5 & 156.5 & 118.2 & 100.0 & 79.7 & 29.9 \\
\hline Net home equity/total assets ${ }^{\mathrm{b}}$ & 21.4 & 18.8 & 21.3 & 20.9 & 18.1 & 23.4 & 28.7 \\
\hline $\begin{array}{l}\text { Principal residence debt/house } \\
\text { value }\end{array}$ & 34.9 & 65.4 & 51.4 & 38.3 & 29.2 & 16.9 & 4.9 \\
\hline All stocks/total assets ${ }^{c}$ & 16.8 & 5.9 & 11.2 & 15.1 & 19.4 & 21.5 & 20.0 \\
\hline
\end{tabular}

Source: own computations from the 2007 Surveys of Consumer Finances. Households are classified into age class according to the age of the household head.

a. Financial securities exclude U.S. government savings bonds in this tabulation

c. Ratio of gross value of principal residence less mortgage debt on principal residence to total assets.

b. Includes direct ownership of stock shares and indirect ownership through mutual funds, trusts, and IRAs, Keogh plans, 401(k) plans, and other retirement accounts

The gross value of the principal residence comprised over half the value of total assets for age group 35 and under, and its share of total assets fell 
off with age to about a quarter for age group 55-64 and then rose to 30 percent for age group 75 and over. Liquid assets as a share of total assets remained relatively flat with age group at around 6 percent except for the oldest group for whom it was 11 percent, perhaps reflecting the relative financial conservativeness of older people. Pension accounts as a share of total assets rose from 4 percent for the youngest group to 16 percent for age group 55 to 64 and then fell off to 5 percent for the oldest age group. This pattern likely reflects the build-up of retirement assets until retirement age and then a decline as these retirement assets are liquidated. ${ }^{14}$

Corporate stock and financial securities showed a steady rise with age, from a 4 percent share for the youngest group to a 26 percent share for the oldest. A similar pattern was evident for total stocks as a percentage of all assets. Unincorporated business equity and non-home real estate was relatively flat as a share of total assets with age, about 30 percent.

There was a pronounced fall off of debt with age. The debt to equity ratio declined from 93 percent for the youngest group to 2 percent for the oldest, the debt to income ratio from 168 percent to 30 percent, and principal residence debt as a share of house value from 65 to 5 percent. As a result of the latter, net home equity as a proportion of total assets rose from 19 to 29 percent from the youngest to oldest age group.

Younger households were thus more heavily invested in homes and more heavily in debt whereas the portfolio of older households was more heavily skewed to financial assets, particularly corporate stock. As a result, younger households benefit relatively when housing prices rise and inflation is strong while older households benefit relatively from rising stock prices. Conversely, younger households were much more exposed to the home price collapse of 2007-2007 than older ones while older households were more vulnerable to the stock market crisis of 2007-2009 than younger ones. Changes in the relative net worth position of age groups over the 1983 to 2007 period were largely due to these relative asset price movements.

\section{Stock Ownership First Rises and Then Falls}

Tables 10a reports on overall stock ownership trends from 1989 to 2007. ${ }^{15}$ The years 1989 to 2001 saw a substantial increase in stock ownership. The share of households with direct ownership of stock

\footnotetext{
${ }^{14}$ This pattern may also be partly a cohort effect since 401(k) plans and other defined contribution plans were not widely introduced into the workplace until after 1989.

${ }^{15}$ The 1983 data do not permit an estimation of indirect stock ownership, so that I exclude 1983 from the table.
} 
climbed from 13 percent in 1989 to 21 percent in 2001, while the share with some stock owned either outright or indirectly through mutual funds, trusts, or various pension accounts surged from 32 to 52 percent. Much of the increase was fuelled by the growth in pension accounts like IRAs, Keogh plans, and 401(k) plans. Between 1989 and 2001, the share of households owning stock through a pension account more than doubled, accounting for the bulk of the overall increase in stock ownership. Indirect ownership of stocks through mutual funds also greatly expanded over the 1989-2001 period, from 6 to 17 percent, as did indirect ownership through trust funds, from 1.6 to 5.1 percent. All told, the share of households with indirect ownership of stocks doubled, from 24 percent in 1989 to 48 percent in 2001.

Table 10a - Stock Ownership, 1989, 2001, and 2007 (percent of households holding stocks)

\begin{tabular}{|c|c|c|c|}
\hline Stock Type & 1989 & 2001 & 2007 \\
\hline Direct stock holdings only & 13.1 & 21.3 & 17.9 \\
\hline Indirect stock holdings only & 23.5 & 47.7 & 44.4 \\
\hline 1. Through mutual funds & 5.9 & 16.7 & 10.6 \\
\hline 2. Through pension accounts & 19.5 & 41.4 & 40.2 \\
\hline 3. Through trust funds & 1.6 & 5.1 & 4.1 \\
\hline \multicolumn{4}{|l|}{ All stock holdings ${ }^{a}$} \\
\hline 1. Any holdings & 31.7 & 51.9 & 49.1 \\
\hline 2. Stock worth $\$ 5,000$ or more ${ }^{b}$ & 22.6 & 40.1 & 34.6 \\
\hline 3. Stock worth $\$ 10,000$ or more & 18.5 & 35.1 & 29.6 \\
\hline 4. Stock worth $\$ 25,000$ or more ${ }^{b}$ & 10.5 & 27.1 & 22.1 \\
\hline \multicolumn{4}{|l|}{ Memo: } \\
\hline Direct plus indirect stocks as a percent of total assets & 10.2 & 24.5 & 16.8 \\
\hline
\end{tabular}

Source: own computations from the 1983, 1989, 2001, and 2007 SCF.

a. Includes direct ownership of stock shares and indirect ownership through mutual funds, trusts, and IRAs, Keogh plans, 401(k) plans, and other retirement accounts.

b. 1995 dollars.

Table 10b - Distribution of Stock Ownership by Asset Type, 1989-2007 (percent of total stock held in each asset type)

\begin{tabular}{lrrrr}
\hline \multicolumn{1}{c}{ Stock Type } & $\mathbf{1 9 8 9}$ & $\mathbf{2 0 0 1}$ & $\mathbf{2 0 0 7}$ & $\begin{array}{r}\text { Change } \\
\mathbf{1 9 8 9 - 2 0 0 7}\end{array}$ \\
\hline Direct stock holdings & 54.0 & 38.5 & 37.1 & -16.9 \\
Indirect stock holdings only & 46.0 & 61.5 & 62.9 & 16.9 \\
$\begin{array}{l}\text { 1. Through mutual funds } \\
\text { 2. Through pension accounts }\end{array}$ & 8.5 & 16.0 & 21.3 & 12.8 \\
3. Through trust funds & 24.4 & 33.5 & 31.4 & 7.0 \\
Memo: & 13.2 & 12.0 & 7.2 & -6.0 \\
Stocks held in pension accounts/total value of pension & & & & \\
accounts & 32.6 & 66.3 & 43.6 & 11.1 \\
\hline \hline
\end{tabular}

Source: own computations from the 1983, 1989, 2001, and 2007 SCF.

a. Includes direct ownership of stock shares and indirect ownership through mutual funds, trusts, and IRAs, Keogh plans, 401(k) plans, and other retirement accounts 
In contrast, the next six years, 2001-2007, saw a retrenchment in stock ownership. This trend probably reflected the sharp drop in the stock market from 2000 to 2001, its rather anaemic recovery through 2004, and its modest rebound from 2004 to 2007. Direct stock ownership plummeted from 21 percent in 2001 to 18 percent. Indirect stock ownership fell by 3.3 percentage points from 2001 to 2007. This decrease was largely due to a sharp decline in stock ownership through mutual funds (down by 6 percentage points). Stock ownership through pension accounts was down by 1.2 percentage points from 2001 to 2007.

By 2007 the share of households who owned stock directly or indirectly dipped below half, down to 49 percent and down from its peak of 52 percent in 2001. Moreover, many of these families had only a minor stake in the stock market in 2007, with only 35 percent with total stock holdings worth $\$ 5,000$ (in 1995 dollars) or more, down from 40 percent in 2001; only 30 percent owned $\$ 10,000$ or more of stock, down from 35 percent in 2001; and only 22 percent owned $\$ 25,000$ or more of stocks, down from 27 percent six years earlier.

Direct plus indirect ownership of stocks as a percent of total household assets did more than double from 10 in 1989 to 25 in 2001. This increase may reflect in large measure the 171 percent surge in stock prices over these years. However, between 2001 and 2007, the share plummeted to 17 percent. This change is a result not only of the relative stagnation of the stock market over these years but also of the withdrawal of many families from the stock market.

Table 10b shows the distribution of total stocks owned by vehicle of ownership. Here there are very marked time trends. Direct stock holdings as a share of total stock holdings fell almost continuously over time, from 54 percent in 1989 to 37 percent in 2007. In contrast, stock held in mutual funds as a share of total stock rose almost continuously over time, from 9 percent in 1983 to 21 percent in 2007, while that held in trust funds declined by 6 percentage points.

The most interesting pattern is with regard to stock held in defined contribution pension accounts (including IRAs). Its share of total stocks first increased from 24 percent in 1989 to 34 percent in 2001 but then fell off to 31 percent in 2007. The trend from 2001 to 2007 seems to reflect a substitution of stock holdings in mutual funds for those in pension plans as investors looked for safer retirement accounts (see below). Likewise the share of the total value of pension plans held as stock more than doubled between 1989 and 2001, from 33 to 66 percent, and then plummeted to 44 percent in 2007. The sharp tail-off in stock ownership in pension plans after 2001 likely reflects the lethargic performance of the stock market over this period and the search for more secure investments among plan holders. 
Stock ownership is also highly skewed by wealth and income class. As shown in Table 11a, 93 percent of the very rich (the top one percent) reported owning stock either directly or indirectly in 2007, compared to 48 percent of the middle quintile and 16 percent of the poorest 20 percent. While 88 percent of the very rich also reported stocks worth $\$ 10,000$ or more, only 22 percent of the middle quintile and 2 percent of the bottom quintile did so. The top one percent of households owned 38 percent of all stocks, the top five percent 69 percent, the top 10 percent 81 percent, and the top quintile over 90 percent.

Table 11a - Concentration of Stock Ownership by Wealth Class, 2007

\begin{tabular}{|c|c|c|c|c|c|c|}
\hline \multirow{2}{*}{ Wealth Class } & \multicolumn{3}{|c|}{$\begin{array}{l}\text { Percent of Households Owning Stock } \\
\text { Worth More Than: }\end{array}$} & \multicolumn{3}{|c|}{ Percent of Stock Owned } \\
\hline & Zero & $\$ 4,999$ & $\$ 9,999$ & Shares & Cumulative & $\begin{array}{c}\text { Cumulative } \\
2001\end{array}$ \\
\hline Top one percent & 92.6 & 89.1 & 88.4 & 38.3 & 38.3 & 33.5 \\
\hline \multicolumn{7}{|l|}{ Next four } \\
\hline percent & 92.2 & 90.7 & 89.5 & 30.8 & 69.1 & 62.3 \\
\hline Next five percent & 86.8 & 85.0 & 81.4 & 12.1 & 81.2 & 76.9 \\
\hline Next ten percent & 82.1 & 77.1 & 71.2 & 9.9 & 91.1 & 89.3 \\
\hline Second quintile & 65.4 & 54.3 & 47.1 & 6.4 & 97.5 & 97.1 \\
\hline Third quintile & 47.7 & 28.9 & 22.1 & 1.9 & 99.4 & 99.3 \\
\hline Fourth quintile & 30.3 & 12.3 & 8.7 & 0.5 & 99.9 & 99.8 \\
\hline Bottom quintile & 16.3 & 3.5 & 2.0 & 0.1 & 100.0 & 100.0 \\
\hline All & 49.1 & 36.3 & 31.6 & 100.0 & & \\
\hline
\end{tabular}

Note: Includes direct ownership of stock shares and indirect ownership through mutual funds, trusts, and IRAS, Keogh plans, 401(k) plans, and other retirement accounts. All figures are in 2007 dollars.

Table 11b - Concentration of Stock Ownership by Income Class, 2007

\begin{tabular}{|c|c|c|c|c|c|c|c|}
\hline \multirow{2}{*}{ Income Level } & \multirow{2}{*}{$\begin{array}{c}\text { Share of } \\
\text { Households }\end{array}$} & \multicolumn{3}{|c|}{$\begin{array}{c}\text { Percent of Households Owning } \\
\text { Stock Worth More Than }\end{array}$} & \multicolumn{3}{|c|}{ Percent of Stock Owned } \\
\hline & & Zero & $\$ 4,999$ & $\$ 9,999$ & Shares & Cumulative & $\begin{array}{c}\text { Cumulative } \\
2001\end{array}$ \\
\hline$\$ 250,000$ or more & 3.6 & 95.4 & 93.4 & 91.3 & 53.7 & 53.7 & 40.6 \\
\hline$\$ 100,000-\$ 249,999$ & 15.5 & 84.5 & 71.0 & 63.7 & 21.5 & 75.2 & 68.6 \\
\hline$\$ 75,000-\$ 99,999$ & 10.4 & 71.1 & 55.6 & 49.6 & 9.0 & 84.3 & 77.4 \\
\hline$\$ 50,000-\$ 74,999$ & 17.5 & 58.1 & 40.7 & 34.9 & 7.7 & 92.0 & 89.3 \\
\hline$\$ 25,000-\$ 49,999$ & 27.1 & 39.3 & 23.6 & 19.0 & 5.7 & 97.7 & 97.6 \\
\hline$\$ 15,000-\$ 24,999$ & 12.7 & 23.1 & 15.7 & 11.9 & 1.1 & 98.8 & 98.9 \\
\hline Under $\$ 15,000$ & 13.3 & 11.2 & 5.0 & 4.3 & 1.2 & 100.0 & 100.0 \\
\hline All & 100.0 & 49.1 & 36.3 & 31.8 & 100.0 & & \\
\hline
\end{tabular}

Stock ownership also tails off by income class (see Table 11b). Whereas 94 percent of households in the top 3.6 percent of income recipients (those who earned $\$ 250,000$ or more) owned stock in 2007,39 percent of the middle class (incomes between 25 and 50 thousand), 23 percent of the lower middle class (incomes between 15 and 25 thousand), and only 11 percent of poor households (income under $\$ 15,000$ ) reported stock 
ownership. The comparable ownership figures for stock holdings of $\$ 10,000$ or more are 91 percent for the top income class, 19 percent for the middle class, 12 percent for the lower middle class, and 4 percent for the poor. Moreover, 84 percent of all stocks were owned by households earning $\$ 75,000$ or more (the top 30 percent) and 92 percent by those earning $\$ 50,000$ or more in terms of income.

Another notable development in the 2000s was an increase in the concentration of stock ownership, as shown in the last column of Tables $11 \mathrm{a}$ and $11 \mathrm{~b}$. The share of total stock owned by the richest one percent in terms of wealth increased from 34 percent in 2001 to 38 percent in 2007 and that of the richest 5 percent from 62 to 69 percent. In terms of income, the share of total stock owned by the top income class jumped from 41 to 54 percent (though, it should be noted their share of total households also rose, from 2.7 to 3.6 percent) and that of the top two income classes from 69 to 75 percent. One result of the stock market bust of the early 2000s was a withdrawal of middle class families from the stock market.

Thus, in terms of wealth or income, substantial stock holdings have still not penetrated much beyond the reach of the rich and the upper middle class. The big winners from the stock market boom of the late 1990s (as well as the big losers in the early 2000s) were these groups, while the middle class and the poor did not see sizable benefits from the bull market (or losses when the stock market tanked in 2000-2002). It is also apparent which groups were most exposed to the 2007-2009 stock market crash.

\section{An Update to 2009}

A complete update of the wealth figures to 2009 is beyond the scope of the present study. However, it is possible to provide a partial update of the wealth figures to July 1, 2009 based on two notable developments. The first is that house prices fell by 24 percent in real terms, ${ }^{16}$ and the second is that the S\&P 500 index was down by 41 percent in real terms. A somewhat rough update, based on the change in housing and stock prices shows a marked deterioration in middle class wealth. ${ }^{17}$ According to my estimates, while mean wealth (in 2007 dollars) fell by 17.3 percent between 2007 and 2009 to $\$ 443,600$, median wealth plunged by an astounding 36.1 percent to $\$ 65,400$ (about the same level as in 1992!).

Trends in inequality are also important. According to previous research (Wolff, 2002), wealth inequality is very sensitive and positively related to

\footnotetext{
${ }^{16}$ This figure is based on the National Association of Realtors Median Sales Price of Existing Single-Family Homes for Metropolitan Areas.

${ }^{17}$ I assume that there are no additional savings (or dissavings) and no portfolio adjustments (except those caused by price changes of homes and stock).
} 
the ratio of stock prices to housing prices, since the former is heavily concentrated among the rich and the latter is the chief asset of the middle class. The fact that stock prices fell more than housing prices, at least from 2007 to mid-2009 should lead to a decline in wealth inequality over these two years. However, instead, the results show a fairly steep rise in wealth inequality, with the Gini coefficient climbing from 0.834 to 0.865 . The share of the top one percent advanced from 34.6 to 37.1 percent, that of the top 5 percent from 61.8 to 65.0 percent, and that of the top quintile from 85.0 to 87.7 percent, while that of the second quintile fell from 10.9 to 10.0 percent, that of the middle quintile from 4.0 to 3.1 percent, and that of the bottom two quintiles from 0.2 to -0.8 percent. There was also a large expansion in the share of households with zero or negative net worth, from 19 to 24 percent.

On the surface, these results appear somewhat surprisingly in light of the earlier results. However, while stock prices fell more than house prices, houses were a much larger share of the gross assets of the middle class than stocks were of the rich. As shown in Table 5, homes comprised 65 percent of the gross assets of the three middle wealth quintiles in 2007, whereas stocks made up 21 percent of the gross assets of the top one percent and 19 percent of the next richest 19 percent of households. As a result, the middle class took a bigger relative hit from the decline in home prices on their net worth than the top 20 percent did from the stock market decline. This is also reflected in the fact that median wealth dropped much more in percentage terms than mean wealth. Moreover, the rapid decline in house prices over these two years left 17 percent of homeowners "underwater," with greater mortgage debt than the value of their homes.

\section{Summary and Concluding Comments}

Median net worth showed robust gains over the years from 1983 to 2007. In fact, the growth rate of median accelerated from the 1980s to the 1990s and into the 2001-2007 period. However, the gains of the 2001-2007 period were based largely on rising home prices financed by increasing mortgage debt. This growth came to an abrupt end in 2007 with the collapse in home prices, and median wealth plummeted from 2007 through 2009.

Household wealth inequality showed a sharp increase from 1983 to 1989. However, from 1989 to 2007 there was almost no change in the degree of wealth inequality. This trend was surprising because the two factors normally positively associated with wealth inequality, income inequality and the ratio of stock prices to home prices, both showed a marked rise over the same years, 1989 to 2007. However, according to my 
projections, there was a fairly steep rise in wealth inequality from 2007 to 2009 , as the collapse in housing prices hurt the middle class more than the decline in stock prices affected the rich.

The biggest story for the early and mid 2000s is that, despite the buoyant economy over the 1980s and 1990s, overall indebtedness continued to rise among American families and then shot up in the 2000s. Among the middle class, in particular, the debt-income ratio reached its highest level in 24 years. Mortgage debt on middle class homeowner's property exploded from 29 percent in 1983 to 47 percent in 2007 (and among all homeowners from 21 to 35 percent). The high level of mortgage indebtedness made the middle class particularly vulnerable to the collapse of the housing market at the end of the decade of the 2000s. In fact, I estimate that 17 percent of homeowners were "underwater" by 2009.

Another notable trend is the big increase in the value of homes as a share of total assets from 2001 to 2007 and corresponding fall in the value of stocks held to total assets. As shown above, these two changes largely mirror relative price movements over the period. Pension accounts as a share of total assets also fell off a bit from 2001 to 2007. Net equity in owner-occupied housing as a share of total assets fell from 24 percent in 1983 to 21 percent in 2007, reflecting rising mortgage debt on homeowner's property, which grew from 21 percent in 1983 to 35 percent in 2007.

Evidence of the middle class squeeze is that for the middle three wealth quintiles there was a huge increase in the debt-income ratio from 100 to 157 percent from 2001 to 2007 and an almost doubling of the debt-equity ratio from 32 to 61 percent. Moreover, total stocks as a share of total assets fell off from 13 to 7 percent for the middle class. The debt-equity ratio was also much higher among the middle 60 percent of households in 2007, at 0.61 , than among the top one percent $(0.028)$ or the next 19 percent $(0.121)$.

The mean wealth of African-Americans was only 19 percent that of white families in 1983, and that ratio barely budged over the years from 1983 to 2007. The black homeownership rate did climb from 44 percent in 1983 to 49 percent in 2007, but their homeownership rate relative to white households was the same in 2007 (a ratio of 0.65) as in 1983. The mean wealth of Hispanic households was also very low compared to nonHispanic whites in 1983, a ratio of 0.16 , but Hispanics did show some gains in mean wealth relative to non-Hispanic whites, particularly over years 2001 to 2007, and the ratio advanced to 0.26. The homeownership rate among Hispanic households also ascended from a meagre 33 percent in 1983 to 49 percent in 2007, the same level as African-Americans, and the ratio of homeownership rates between Hispanics and non-Hispanic whites advanced from 48 percent in 1983 to 66 percent in 2007.

Young households (under the age of 45) after some relative gains from 1983 to 1989, saw their relative wealth position deteriorate over the years 
1989 to 2007. This development made young households particularly exposed to the joint collapse of the stock and housing markets at the end of the decade of the 2000s. 


\section{References}

Blau, F.D., \& Graham, J.W. (1990). Black-White Differences in Wealth and Asset Composition. Quarterly Journal of Economics, 105(1), 321-339.

Gittleman, M., \& Wolff, E.N. (2004). Racial Differences in Patterns of Wealth Accumulation. Journal of Human Resources, 39(1), 193-227.

Kennickell, A.B. (2001). Modeling Wealth with Multiple Observations of Income: Redesign of the Sample for the 2001 Survey of Consumer Finances. SCF Working Papers. Retrieved from http://www.federalreserve.gov/pubs/oss/oss2/method.html

Kennickell, A.B., \& Woodburn, R.L. (1992). Estimation of Household Net Worth Using Model-Based and Design-Based Weights: Evidence from the 1989 Survey of Consumer Finances. Federal Reserve Board of Washington. SCF Working Papers. Retrieved from http://www.federalreserve.gov/pubs/oss/oss2/papers/concentration.198 9.final.pdf

Modigliani, F., \& Brumberg, R. (1954). Utility Analysis and the Consumption Function: An Interpretation of Cross-Section Data. In Kurihara, K. (Ed.), Post-Keynesian Economics (pp. 383-436). Brunswick, N.J.: Rutgers University Press.

Oliver, L.M., \& Shapiro, T.M. (1997). Black Wealth/White Wealth: a New Perspective on Racial Inequality. New York: Routledge.

U.S. Council of Economic Advisers. (2009). Economic Report of the President 2009. Washington, DC: United States Government Printing Office.

Wolff, E.N. (1987). Estimates of Household Wealth Inequality in the United States, 1962-83. Review of Income and Wealth, 33(3), 231-256. doi:10.1111/j.1475-4991.1987.tb00673.x

Wolff, E.N. (1994). Trends in Household Wealth in the United States, 19621983 and 1983-1989. Review of Income and Wealth, 40(2), 143-174.

Wolff, E.N. (1996). Top Heavy: A Study of the Increasing Inequality of Wealth in America. New York: New Press.

Wolff, E.N. (1998). Recent Trends in the Size Distribution of Household Wealth. Journal of Economic Perspectives, 12(3), 131-150.

Wolff, E.N. (2001). Recent Trends in Wealth Ownership, from 1983 to 1998. In Shapiro, T.M., \& Wolff, E.N. (Eds.), Assets for the Poor: The Benefits of Spreading Asset Ownership (pp.34-73). New York: Russell Sage Press. 
Wolff, E.N. (2002). Top Heavy: A Study of Increasing Inequality of Wealth in America. Newly updated and expanded edition, New York: the New Press.

Wolff, E.N. (2007). Recent Trends in Household Wealth in the United States: Rising Debt and the Middle-Class Squeeze. Levy Economics Institute Working Paper No. 502. 


\section{Appendix: Sources and Methods Used for the Survey of Consumer Finances Data}

\section{A1. Choice of Weights}

In some years, the SCF supplied alternative sets of weights. For the 1983 SCF, I use the so-called "Full Sample 1983 Composite Weights" because this set of weights provides the closest correspondence between the national balance sheet totals derived from the sample and those in the Federal Reserve Board Flow of Funds. For the same reason, results for the 1989 SCF are based on the average of SRC-Design-S1 series (X40131 in the database itself) and the SRC Designed Based weights (X40125). Results for the 2001and 2007 SCF rely on the Designed-Base Weights (X42001) partially design-based weights which are constructed on the basis of original selection probabilities and frame information and adjusted for non-response and which account for the systematic deviation from the CPS estimates of homeownership rates by racial and ethnic groups.

\section{A2. Alignment with the Flow of Funds Data}

The Federal Reserve Board imputes information for missing items in the SCF. However, despite this procedure, there still remain discrepancies for several assets between the total balance sheet value computed from the survey sample and the Flow of Funds data. As a result, the results presented below are based on my adjustments to the original asset and liability values in the surveys. This takes the form of the alignment of asset and liability totals from the survey data to the corresponding national balance sheet totals. In most cases, this entails a proportional adjustment of reported values of balance sheet items in the survey data (see Wolff, 1987, 1994, 1996, and 1998 for details). The adjustment factors by asset type and year are as follows:

$\begin{array}{llc} & 1983 \text { SCF } & 1989 \text { SCF } \\ \text { Checking Accounts } & 1.68 & \\ \text { Savings and Time Deposits } & 1.50 & 1.37 \\ \text { All Deposits } & & \\ \text { Financial Securities } & 1.20 & 1.66 \\ \text { Stocks and Mutual Funds } & 1.06 & \\ \text { Trusts } & & \\ \text { Stocks and bonds } & & \\ \text { Non-Mortgage Debt } & 1.16 & \end{array}$

No adjustments were made to other asset and debt components, or to the 2001 or 2007 SCF. 
It should be noted that the alignment has very little effect on the measurement of wealth inequality - both the Gini coefficient and the quantile shares. However, it is important to make these adjustments when comparing changes in mean wealth both overall and by asset type.

\section{A3. Choice of Price Index}

I use the standard price deflator, the CPI-U, which the U.S. Bureau of Labor Statistics (BLS) has been computing since 1947, to deflate wealth values. The CPI-U has been criticized for overstating the rate of inflation. As a result, the BLS also provides an alternative consumer price series called the CPI-U-RS (the "RS" stands for "research series.") The CPI-U-RS series makes quality adjustments for housing units and consumer durables such as automobiles and personal computers and employs a geometric mean formula to account for consumer substitution within CPI item categories. As a result, the CPI-U-RS deflator is not subject to the same criticisms as the CPI-U series. Indeed, the Current Population survey (CPS) data are now normally deflated to constant dollars by the U.S. Bureau of the Census using the CPI-U-RS price index.

While the CPI-U-RS deflator incorporates quality and other adjustments, the adjustments are made only from 1978 to the present. The CPI-U index is used for years prior to 1978. The CPI-U-RS shows a much slower rate of inflation after 1973 than the CPI-U: 288 versus 238 percent. If we use the CPI-U-RS deflator, then constant dollar median family income would show a 22 percent growth between 1973 and 2000, in comparison to the 6 percent growth rate on the basis of the CPI-U deflator.

While the use of the CPI-U-RS will show a higher growth in real incomes (and wealth) since 1978, it is not clear that the degree of bias in the CPI has risen in recent years. If similar adjustments were made on the pre-1978 price data, it is possible that the inflation rate over the 1947-1978 period would be adjusted downward by a similar amount as the post-1978 inflation rate. Since my aggregate time-series data on wealth begin in 1922 and I have made calculations of household wealth trends on the basis of micro-data beginning in 1962, I have elected to use the CPI-U series to convert nominal values to real dollars to be consistent with my earlier work on the subject, since the CPI-U series is the only consumer price series that runs from 1922 to the present (see, for example, Wolff, 1987, 1994, and 2002). 